\title{
О ЈЕДНОМ НАЧИНУ ПРЕДБРАЧНОГ ПРОРИЦАЊА МЕБУ СРБИМА У РУМУНИЈИ
}

\begin{abstract}
Током теренског истраживања у српским селима Клисуре (2017) и Пољадије (2019) у Румунији, забележена су два казивања о томе како мајка и ћерка стасала за удају предсказују име ћеркиног „суђеника” користећи шипку од задњег вратила. Казивања ће бити анализирана компаративно, с фокусом на тачке подударања (време, радње, магијски објекат, жељени ефекат), а резултати ће бити упоређени са сличним обичајем етнографски забележеном међу Карашевцима. Биће сагледани у ширем контексту семиотичких веза и паралела које се тичу акционих и предметних кодова који се тичу ткања, разбоја и његових делова.
\end{abstract}

Кључне речи: Срби у Румунији, Пољадија, предбрачно прорицање, ткање, шипка вратила.

Током теренских истраживања у већински српским селима на територији Клисуре (13-15. јун 2017 и Пољадије 11-14. јун 2019)³ забележена су два казивања жена о специфичном начину предбрачног предсказивања у вези са именом мушкарца за кога ће се девојка удати. Овдећу представити транскрипте најинформативнијих делова ових казивања, анализираћу их компаративно и указати на основне координате њихове даље семиотичке анализе. Обичај о којем ће бити речи је изобичајен данас - што, међу другим факторима, свакако има везе с тим да се ова врста предсказивања обавља непосредно након окончаног ткања, а данас готово да нема куће у којој се још увек тка. Казивања овог типа сам забележила смо код две казивачице (разговоре сам водила са њих девет). Једна казивачица (рођена 1927. год.) пореклом је била из Ланговета (Луговета), а удата у Соколовцу (оба села су у Пољадији), док је друга казивачица (рођена 1932. год.) била родом из Соколовца, а удата у

\footnotetext{
${ }^{1}$ djordjina.trubarac@ei.sanu.ac.rs

${ }^{2}$ Овај прилог је настао као резултат рада у Етнографском институту САНУ који финансира Министарство просвете, науке и технолошког развоја РС, а на основу Уговора о реализацији и финансирању научноистраживачког рада НИО у 2021. години број: 451-03-9/202114/200173.од 05.02.2021.

${ }^{3}$ Теренска истраживања су обављена у оквиру рада на пројекту Истраживаъе културе $и$ историје Срба у Румунији (2016-2019) под руководством проф. др Михаја Радана, а који су финансијски и логистички подржали Савез Срба у Румунији и Центар за научно истраживање културе Срба у Румунији.
} 
Белобрешкој (Клисура). Ово би указивало на то да се обичај о којем ће бити речи вероватно дуже задржао у Пољадији, ако га је у Клисури уопште и било. Ипак, морало би бити да га је барем спорадично било, пошто су се девојке из Пољадије ипак удавале за Клисурце - што је и случај једне од казивачица - а овај начин предвиђања је, по природи ствари, првенствено преносила мајка на ћерку. Постоји велика вероватноћа да се „врачање помоћу шипке од вратила да би се дознало име суђеника" (Димитријевић, 1958: 237), а које се помиње у студији Банатске Хере (1958) односи управо на ову данас изобичајену праксу. У тој студији се о њој наводи тек горецитирани штури податак без икаквих подробнијих информација у вези са начином на који је ово предвиђање вршено. Када га помиње, Софија Димитријевић не пружа податак у којим херским селима је забележила овај обичај, те не знамо да ли је пре седамдесетак година ове праксе било и међу банатским Херама са српске стране државне границе, или је податак ипак изнет на основу бележења у Пољадији (чије српско становништво спада у банатске Хере). Сем поменутих података, располажемо и описом варијанте истог обичаја који је забележила Мила Томић међу Карашевцима у другој половини двадесетог века (прем. Сикимић, 1998: 172), па ће и он накнадно бити анализиран и упоређен са моделима забележеним у Клисури и Пољадији.

\section{Казивање бр. 1:}

Разговор са Веселинком Николић (1927), рођена Симоновић, пореклом из Ланговета (Луговета), вођен је 13. јуна 2019. у Соколовцу, селу у које се удала и где је провела остатак живота. Снимак је архивиран под: ЂТМ Соколовац 2C; секвенца целог разговора на тему предвиђања имена будућег мужа: 10:10 - 14:20.

BH: Ја знам још у Ланговет кад сам била, моја мати кад тка, знате, ондак има шипка једна од тога разбоја, од тог материјала што тка и кад се заврши то, то ткање, ондак ми да у шака то и да журим да изиђем до сокака [шаком десне руке показје као да испред себе држи шипку у руци у вертикалном положају]. И кад изиђем на сокак, кога првог видим, каже, тако ће име да ми буде момак. [...] И може да буде да је истина то. Јао кад сам ја изашла на сокак, а био један Цвеја, неки велики тако [управља главу и поглед на горе, ка плафону]: - Иии, јао ирна ја, ја мала, а тај велики, ирна ја, како, ди ћу-мислим. Каже то ће ми буде суђеник. Јао, уђем ја унутра, кажем ја - Цвеју Ђуринога - реко' - сам видела. Па каже - Суђено ти име човеку Цвеја, момку Цвеја. [...] Кад тамовамо [удара дланом о длан] дош'о из Соколовца Цвеја, ме исти, био је и овај велики, већи од мне, само није био баш толики велики, а Цвеја исто...

ЂТМ.: Исто је Цвеја! [...]

А како се зове тај штап што сте Ви држали у руци? То што изађете на сокак ? ВН: Па не могу се сетим... знала сам то, то је било там бележено све, не мог'да се сетим $[\ldots]$ 
ЂТМ: А за шта је он служио? Када ткате, за шта је он служио?

BН: Е знате за шта је он служио, па служио што је он, како да вам кажем, кад се тка то платно, знате, па ондак подметну, знате, кад се тка па се то вуче да се ово купи [показује рукама], тако ондак то.. колико мало откате, затегне отуд, затегне одовуд да би ишло право то платно.

ЂТМ: А штап, шта радите са њим?

ВН: Тај штап иде како се тка платно тако иде... иде испред ово што се завија, а то иде све испред ка концима, ка нитама, знате, да не би се купило.

\section{Казивање бр. 2}

Разговор је вођен 13. јуна 2017. год. у Белобрешкој. Казивачица: Ђурђевка Несторовић, (Соколовац, 1932 - Белобрешка 2019), рођена Драшковић. Снимак је архивиран под: ЂT, Белобрешка, 1Dc 13.06.2017. Секвенца целог разговора на тему предбрачног предвиђања: 23:20-26:45.

ЂН: А да вам каже мајка ово: кад је моја мати ткала - да знате да има и о томе - кад је моја мати ткала, у разбоју је имала, је ткала млого, млого, једну годину девет пут је разбој награђивала, ткала, једну зиму, она каже мени - Бекна, знаш шта? - Сестра већ ми се била удала. - Мама, сад кад ово испадне, ова иипка што држи поред вратила конац да буде затегнут, кад испадне шипка, сад кад дотерам до шипке, пуштим вратило - каже - и шипка ће да испадне. Ти ћеш да узмеш ту шипк..., ја ћу да узмем шипку и ћу да 'итнем кроз прозор на улииу, и ти изиђи - на врата смо улазили, била и капија велика, ал' на врата смо улазили ми тако; кола и стока излазила на капију, а ми кроз врата, патосано са циглом све поред куће - а ти изађи - каже - пред кућу да узмеш шипку да видии кога ћеш да видиш.

ЂТМ: Тако она баци шипку кроз прозор?

ЂН: Кроз прозор ми бацила на улицу шипку.

ЂTM: А ви сте чекали доле...

ЂН: А ја сам отишла да видим да узмем шипку и да видим некога да прође. Кад сам отишла пред кућу да узмем шипку - девојка, комшинка, млађа него ја, Љуба се зове и мој теча један, Миливој, био ковач, моје маме сестрица била за њега, теча Миливој на сокак. Кад сам, узела сам шипку, ушла сам унутра, моја мати каже - Шта је било, кога си видела? - Па силан ми момак?! Љубу Шкрнетину сам вид'ла и теча Миливоја - реко'. Па каже - Ништа, кога си вид 'ла, вид 'ла. Кад после, мој Љуба, он је Миливој, право му име Миливој, ал' Љубо га сви звали, мазили што се каже.

ЂТМ: Стварно? То му био надимак Љуба, у ствари.

ЂН: Да. Па да’л је то судбина, да'л то... Ето то сам провела и то могу да проповедам и на онај свет! Да, то сам, што су рекли... није било нека враџбина ил' нешто, то је... Моја мати каже - Ја када се удајем, баба је опет 'итнула y двориште иипку кроз прозор - и она каже узела шипку и комшинка виче - Живо! - сина - Живо! И мој отац се звао Живо. Ето. Да'л то је судбина, да изиђе тај моменат, тај глас, тај вид пред тебе. Зато мајка вам каже, то сам, што су рекли, видела и провела и то није нека лаж, ил' нешто. То сам вид’ла, и 
сам ето, нит'... нит' сам знала Љубу, нит' познавала. Он из Белобрешке, ја из Соколовца. Нити сам ја ишла вамо дигод доле, по... по Клисури, по... нисам ни ја њега знала ни он мене. И кад дош'о, ето нисам 'тела одма' на удају... и да се сретнемо и да се саставимо и... и ето.

ЂТМ: Био Вам је суђен дефинитивно.

$[\ldots]$

ЂН: Да, ми је био суђен тако, име то, баш два имена да има.

Уследило је моје питање у вези са тиме шта каже народ, да ли постоји судбина, на шта је казивачица почела да говори о ,три милостиве” које одређују судбину детета након рођења - добро документованим веровањима међу већином словенских и других индо-европских народа у три митске господарице судбине (међу балканским Словенима обично називаним суђајама), а које имају исте митске корене са античим моирама и паркама. ${ }^{4}$

У казивању бр. 2 имамо казивање у казивању, тј. казивачицину реконструкцију казивања њене мајке, коју она износи на основу сопственог сећања, а која се тиче исте врсте прорицања. Тако располажемо са три модела ове праксе која имају значајан број додирних тачака, али и извесна међусобна одступања.

\section{Компаративна анализа забележених модела}

Сва три поменута модела имају низ заједничких елемената: 1) време када се прорицање врши поклапа се са тренутком непосредно након окончаног ткања једног комада тканине; 2) место радње је двојако: 1. унутар куће, крај разбоја; 2. изван куће, на отвореном; 3) актери су у свим случајевима мајка, ћерка стасала за удају и „случајни” доносилац/доносиоци информације о имену будућег мужа; 4) реквизит који се користи је шипка од задњег вратила на ткачком разбоју; 5) резултат је истинито сазнање о имену (па и надимку) будућег мужа, којег бар у два поменута случаја, девојка није познавала у тренутку прорицања. Разлике су видне у следећим детаљима: 1) у оба модела која сусрећемо у казивању бр. 2 мајка, након пада шипке, узима шипку и баца је кроз прозор, док ћерка треба одмах да истрчи напоље и узме шипку, док у казивању бр. 1 изостаје бацање шипке кроз прозор, али и даље је присутно то да мајка узима шипку и даје је ћерки, те из сва три модела видимо да шипку након њеног пада рукама прво дохвата мајка; 2) модели у казивању бр. 2 се разликују и по томе што у једном мајка шипку баца на улицу, а у другом у двориште; 3) у моделима се доносилац/доносиоци информације о имену разликују по природи (у два казивања то су људи, у

\footnotetext{
${ }^{4}$ О овој теми је већ доста писано, рецимо, в. СМР: 427-428 под суђенице; Зечевић, 1981: 77-84; Требјешанин, 1968; Бандић, 1991: 170-173. За шири словенски контекст, в. СМЕР: 518-521, под суђенице.
} 
једном је то глас који се зачује) и по броју (у једном случају се појављују две особе чија имена откривају како име тако и надимак „суђеника”). Наравно, ова последња разлика је ирелевантна с аспекта семиотичке анализе овде описаних магијских радњи, јер улази у домен активности „више силе”, а не самих људских актера.

Временско везивање прорицања за тренутак одмах након завршеног ткања ${ }^{5}$ ослања се на семиотизацију границе као такве, па и граничног времена као неке врсте међувременског момента, тренутка који не припада ниједном времену (једно ткање се завршило, а разбој за друго тек треба да се „награди”), који као такав резонира са животном доби у којој се налази девојка која тражи одговор у вези са својим „суђеником”. Овако семиотизован исечак времена такође функционише као својеврсна временска капија између линеарног тока људске перцепције протока времена и безвремено-свевремене зоне (у којој паралелно постоје прошлост, садашњост и будућност), а из које је једино и могуће добити информацију коју девојка и мајка ишчекују. Све ово семиотички се директно ослања на неке од основних идеја које се генерално у традиционалној култури народа широм света везује за радње које се тичу обликовања нити (предење) и манипулације њима (ткање, плетење), а којима се приписује симпатетичка веза с утицањем на предење „нити живота” и „плетење судбине”: издвајање нити из неуобличене масе, намотавање на преслицу као космичку осу и коришћење за стварање нових облика даљим уплитањем. У магијском смислу све ове радње отварају могућност за међусобно сједињавање различитих садржаја за нит/тканину у самом чину предења/ткања и то навођењем речи/стања/радњи/мисли у одређеном правцу и уплитањем жељених садржаја у живот/судбину оног који буде у контакту са тим нитима/тканином - отуда и честа употреба нити, тканина и реквизита за предење и ткање у магијским радњама. ${ }^{6}$

Што се употребе шипке од задњег вратила тиче 7 , њу треба посматрати као магијски објекат аналоган задњем вратилу, с тим што је њоме, због њене тежине и нефиксираности знатно лакше хитро манипулисати у магијске

\footnotetext{
${ }^{5}$ О разнородним варијантама симболике и значења ткања, као и његовог почетка и краја који се јављају у читавој парадигми предбрачних и свадбених обичаја и веровања у ширем словенском контексту, в. Гура, 2011. Такође, за више података о свадбено-обредним и магијским функцијама и конотацијама ткања, разбоја и његових делова в. Сикимић, 1998: $165-176$.

6 За сумиране неке од употреба преслице, вратила и вретена у магијске сврхе в. СМЕР под вратило, вретено и СМР под вратило, вретено, преслица; Сикимић, 1998: 165-176; Трубарац Матић, 2017: 428-429; 2019: 193-195. За исто у македонском фолклору, в. Макаријоска, 2020: 375-376.

7 За њу су у југоисточној Србији забележени и називи затеза́sћа, наврта́љка, поврата́ло, поврта́ло, поврта́љка, поврта́љћа, поврта́ч (Марковић, 2006: 26), а у Пивској планини uтап и запињача (Цицмил-Реметић, 2020: 720, 723, 729). За македонске називе, в. Лаброска, 2020: 341 .
} 
сврхе него што је то случај са задњим вратилом. Семиотичко поље вратила је сложена тема коју треба сагледавати у оквиру семиотизације целокупног разбоја, те се овде тиме не могу бавити, већ бих у вези са вратилом указала на то да је кружно кретање око осовине/средишта (реално постојећих или замишљених), радња са израженим космогонијским предзнаком, која је у директној вези са идејама градње, разградње и реинтеграције космоса и свега што унутар њега постоји у времену (Трубарац Матић, 2017: 428-429), као и да се осовина (семиотизована као космички центар) може обредно и магијски побуђивати ${ }^{8}$, али и измештати и везивати за некога (често актера магијске радње), чиме се стиче контрола над објектом те радње - рецимо, у љубавној магији, где девојка/девојке изговарају формуле типа како се вретено врти, тако се момак/момции вртели око мене (као илустрацију, в. примере у Станојевић, 1929: 46-47; СМР под вретено).

За нас је овде од посебног значаја податак из Македоније (Ресан), где је међу називима за задње вратило забележено и машко кросно (за разлику од предњег које се назива женско кросно) (Лаброска, 2020: 340-341). Ово указује на постојање бинарне опозиције на релацији мушко : женско пројектоване на ове делове разбоја који су и у просторно-хоризонталној равни супротно позиционирани. То расветљава логику употребе баш шипке задњег вратила у овој врсти предбрачног прорицања, јер се она овде јавља као предметни коิд за мушкарца. Мајчиним бацање шипке кроз прозор, односно њеног давања шипке ћерки, остварује се маркирање двојаког измештања осовине/центра (маркираног као мушког): он прво (унутар куће) након пада с разбоја бива измештен у мајчине руке (која је домаћица тог простора и удата жена, па је у њеним рукама шипка знак за мужа/домаћина), а затим се из њених руку та шипка измешта у ћеркине руке, која у простору изван куће чека на глас/особу, који ће означити „суђеника”. Тако се девојчиним држањем шипке и чекањем ван куће на глас/особу остварује комуникацијска магијска спона на релацији муж : девојка : име суђеника.

Велики број етнографских и фолклорних података сведочи о томе да је разбоју, његовим конструктивним елементима, као и самој радњи ткања приписиван низ опсцених конотација (в. Сикимић, 1998: 165-176), па би у том кључу шипка могла имати и фалусно значење. Ипак, с аспекта тумачења овог обичаја то је сасвим ирелевантно, јер је и корпус опсцених конотација везаних за разбој и ткање плод секундарне семиотизације ${ }^{9}$, док обичај о коме је овде реч почива на семиотичкој потки у чијем корену су космогонијске

\footnotetext{
${ }^{8}$ Рецимо, о космогонијском значењу обредног окретања на витлу и сл. обредним радњама, в. Трубарац Матић, 2017. На истој логици почивају и обредне игре и кола која подразумевају кружно кретање.

9 На ово је с правом указала Биљана Сикимић, говорећи о „секундарној еротизацији” и „секундарној хуморизацији” онда када се дође до измештања из обредног у секуларни контекст, в. Сикимић, 1998: 179-180.
} 
(значи митско-религијске) семиотичке пројекције на разбој, јер се тичу концепата као што су време, судбина, уплитање двају судбина (девојке и суђеника), бинарност (полова) као предуслов за рађање (не стварање!) нових облика (разбој) итд.

Варијанта ове врсте предбрачног прорицања постојала је и међу Карашевцима (Равник). Податке о њој је забележила Мила Томић, а ја се овде у потпуности ослањам на препис из њеног рукописа (прем. Сикимић, 1998: 172):

Чине девке. Кет жена тке па јој падне штапак, ондак онеј штапак узме девка у уста и иде, жми, затвори очи. Жмећи иде на сукак, кога ла да види. Ја не знам, или кога види, за тога ла да се уда. Или откуда иде неки, ис тог сокака ла да јој муш.

Из овог казивања се јасно види да се већина просторно-временских, предметних и акционих кодова присутних у њему поклапа са онима из раније анализираних модела, с тим што се главно одступање састоји у томе што девојка треба шипку да изнесе држећи је у устима и то тако што ће жмурити све док не изађе из куће на улицу. Држање шипке у устима директно спречава девојку да ишта изусти док не изађе на улицу, тј. спречава је да се њен глас чује пре оног који ће јој донети име суђеника. Ипак, биће да се овде ради и о другим функцијама и значењима, поготову оних који су присутни у читавој парадигми обичаја, веровања и пракси везаних за зев (било какав) и провлачење кроз њега, а у контексту ткања и делова разбоја, свакако би се то највише односило на зев на разбоју и његових еротско-продуктивних конотација ${ }^{10}$ везаних како за сексуални чин тако и за рађање.

Жмурење током излажења из куће је детаљ који осветљава значење радњи избацивање шипке кроз прозор (казивање бр. 2) и журити на сокак (казивање бр. 1) и могло би да указује на неопходност да се спречи/ минимализује могућност да девојка угледа неког од својих (мушких?) укућана док излази из куће, тј. од момента када је преузела шипку до тренутка када на улици (дакле, у спољашњем простору) угледа неког/ чује нечије име. У првом случају (бацање шипке кроз прозор), то се у потпуности спречава, јер на тај начин девојка ни не може да узме шипку у руке док не изиђе на улицу. У другом случају (што хитрије изаћи напоље) могућност нежељеног сусрета се минимализује. Ово избегавање да се види неко од укућана могло би да буде у вези и са жељом да се избегне девојчино везивање за очинску кућу, у смислу да се никада не уда. Из овог произилази да магијски потенцијал држања шипке од задњег вратила (у моменту када испадне при крају ткања) не покрива само акционо поље предвиђања имена будућег мужа, већ потенцијално и магијског везивања. Овим се отвара и питање изворне функције ових магијских радњи, али и потенцијално

\footnotetext{
${ }^{10}$ О уобичајеном поздраву ткаљама зевом (Оволики ти зев!) акционо праћеним дизањем једне ноге на ширем јужнословенском простору, в. Сикимић, 1998: 173-175.
} 
вршење ове или сличних радњи у циљу љубавног везивања магијским путем - што би ипак тек требало потврдити у даљим истраживањима. У случају наших казивачица, ниједна од њих две није показала свест о учествовању у активности која подразумева магијско деловање на некога (није било нека враибина ил' нешто), већ су касније поклапање имена будућег мужа са именом које су откриле приписивале могућом судбинском предодређеношћу (И може да буде да је истина то / то сам, ито су рекли, видела и провела и то није нека лаж, ил'нешто), пред којом Ђурђевка Несторовић до своје дубоке старости остаје једним делом себе запитана (Да'л то је судбина, да изиђе тај моменат, тај глас, тај вид пред тебе / Па да'л је то судбина, да'л то...), а другим, опет, искуствено сасвим уверена (Ето то сам провела и то могу да проповедам и на онај свет!).

\section{Литература}

Бандић, 1991: Д. Бандић, Народна религија Срба у 100 појмова. Београд: Нолит. Букуров, Филиповић, 1958: Б. Букуров, М. Филиповић, Херска села у Румунији, у: Банатске Хере. (Уредио: Миленко С. Филиповић). Нови Сад: Војвођански музеј, 51-53.

Гура, 2011: А. В. Гура, Ткаческая символика свадьбы, у: Језик, књижевност, култура. Новици Петковићу у спомен. (Уредили: Јован Делић, Александар Јовановић). Београд: Институт за књижевност и уметност - Филолошки факултет Универзитета у Београду, 327-338.

Димитријевић, 1958: С. Димитријевић, Обичаји у личном и породичном животу, у: Банатске Хере. (Уредио: Миленко С. Филиповић). Нови Сад: Војвођански музеј, 232-263.

Зечевић, 1981: С. Зечевић, Митска бића српских предања. Београд: „Вук Караџић”- Етнографски музеј.

Лаброска, 2020: В. Т. Лаброска, Називите на разбојот и на некои делови на разбојот во македонските дијалекти - споредба со називите во југоисточна Србија, у: На темељима народних говора. Зборник радова посвећен проф. др Јордани Марковић поводом одласка у пензију. (Уредиле: Татјана Трајковић, Надежда Јовић). Ниш: Филозофски факултет Универзитета у Нишу, 337-344.

Макаријоска, 2020: Л. А. Макаријоска, За лексиката од областа на ткајачката дејност од етнолингвистички аспект, у: На темељима народних говора. Зборник радова посвећен проф. др Јордани Марковић поводом одласка у пензију. (Уредиле: Татјана Трајковић, Надежда Јовић). Ниш: Филозофски факултет Универзитета у Нишу, 367-379.

Марковић, 1958: 3. Марковић, Предење и ткање, у: Банатске Хере. (Уредио: Миленко С. Филиповић). Нови Сад: Војвођански музеј, 137-142.

Марковић, 2006: J. Марковић, Ткачка лексика Југоисточне Србије. Ниш: Филозофски факултет у Нишу. 
Сикимић, 1998: Б. Сикимић, Неука млада. Београд: Кодови словенских култура 3, 163-185.

СМЕР: Словенска митологија: енциклопедијски речник. (Уредили: Светлана М. Толстој, Љубинко Раденковић). Београд: Zepter Book World, 2001.

CMP: Кулишић, Шпиро, Петар Ж. Петровић, Никола Пантелић. Српски митолошки речник. Београд: Етнографски институт САНУ, 1998 [1970].

Станојевић, 1929: М. Станојевић, Обичаји и веровања на Тимоку. Београд: Гласник Етнолошког музеја 4/4, 42-54.

Цицмил-Реметић, 2020: Р. Б. Цицмил-Реметић, Ткачка терминологија на Пивској планини, у: На темељима народних говора. Зборник радова посвећен проф. др Јордани Марковић поводом одласка у пензију. (Уредиле: Татјана Трајковић, Надежда Јовић). Ниш: Филозофски факултет Универзитета у Нишу, 715-730.

Требјешанин, 1968: Р. Требјешанин, Суђенице као литерарни мотив у приповеткама јужноморавског фолклорног подручја, у: Реферати XIII Конгреса Савеза фолклориста Југославије у Дорјану 1966. године. Скопје: Здружение на фолклористите на СР Македонија, 345-351.

Трубарац Матић, 2017: Ђ. Трубарац Матић, Функционално сагледавање обредног окретања на витлу у Срба. Београд: Гласник Етнографског института 65/2, 421-436.

Трубарац Матић, 2017: Ђ. Трубарац Матић, У јеленовом колу. Мотив јелена у српској обредној лирици. Београд: Етнографски институт САНУ.

\title{
ONE FORM OF FIMALE PRENUPTIAL PREDICTING AMONG SERBS IN ROMANIA
}

\begin{abstract}
Summary
During the fieldwork expeditions carried out in Romanian part of Banat, in the regions of Klisura (June 2017) and Poljadija (June 2019) two testimonies were taken from elder Serbian women, in which they described how, when they were still not married, their mothers had taught them the way to predict the name of their future husband by using a rod of the warp beam. The transcriptions of these testimonies are compared by focusing on their common key elements (time, actions, objects, the manifestation of the expected result), which are analysed from the semiotic perspective and within a broader context of South-Slavic ethnographic material and folklore related to weaving, the loom and its parts, especially their use in magic. A special attention is put on a analysis of a variant of the same type of prenuptial predicting recorded among Krashovani in the second half of the $20^{\text {th }}$ century.
\end{abstract}

Key words: Serbs in Romania, Poljadija, marriage predicting, weaving, loom, rod of the warp beam. 